\title{
COMENTARIOS DEL NUEVO ESTATUTO DEL INVERSIONISTA EXTRANJERO
}

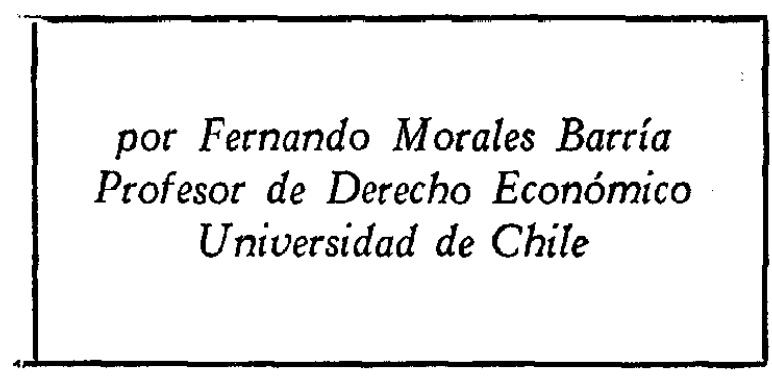




\section{Comentarios del Nuevo Estatuto del Inversionista Extranjero}

En diciembre de 1970, la Gomisión del Acuerdo de Cartagena, órgano máximo del sistema de integración subregional andino, elaboró la Decisión 24 , sobre tratamiento a los capitales extranjeros. Se cumplía así con el mandato expreso que, en tal sentido, estipulaba el Acuerdo de Cartagena.

La Decisión 24 fué, desde su dictación, objeto de interesantes debates jurídicos, que algún día hahrá que analizar exhaustivamente. Desde luego está el problema de la constitucionalidad y legalidad de la puesta en vigencia interna de la Decisión. En seguida, habría que referirse a la situación en que queda la legislación actual sobre inversiones extranjeras, que, si bien debe entenderse derogada en todo lo que sea contrario al Régimen Común, queda vigente en "todo lo que no le sea contrario", y eso es bastante. Finalmente, tendrán que ponderarse las nuevas leyes que sobre estas materias se están dictando (especialmente en Bolivia y Ecuador), y que de alguna manera podrían comprometer el caracter de "común" del Régimen.

Nosotros nos hemos propuesto un objetivo menos ambicioso, pero creemos que igualmente útil, especialmente para el alumno y quién se inicie en el estudio de la Decisión 24. Queremos sistematizar, a través del enunciado de ocho caracteristicas principales, el articulado completo del Régimen Común. Naturalmente, tratamos de responder a la interrogante que presentan algunos artículos controvertidos, y nos detenemos en otros de difícil comprensión. 


\section{LA DECISION 24 DE LA COMISION DEL ACUERDO DE CARTAGENA QUE APROBO EL REGIMEN COMUN DE TRATAMIENTO A LOS CAPITALES EX- TRANJEROS Ý SOBRE MARCAS, PATENTES, LICENGIAS Y REGALIAS.}

El Decreto No 482 de 25 de Junio de 1971, del Ministerio de Relaciones Exteriores, publicado en el Diario Oficial del 30 de Junio de ese mismo año. puso en vigencia en Chile el 'Régimen Común de Tratamiento a los Capitales Extranjeros y sobre Marcas, Patentes, Licencias y Regalías". (En adelante el régimen común).

La Decisión 24 constituye la cuiminación de un largo proceso hacia la reglementación de las relaciones económicas entre el Area Andina y el Capital Extranjero.

El artículo 15 del Tratado de Montevideo señalaba la necesidad de reglamentar los capitales extranjeros. Dice así:

"Para asegurar condiciones equitativas de competencia entre las Partes Contratantes y facilitar la creciente integración y complementación de sus economias, especialmente en el campo de la producción industrial las Partes Contratantes procurarán, en la medida de lo posible armonizar -en el sentido de los objetivos de liberación del presente Tratado- sus regímenes de importación y exportación, así como los tratamientos aplicables a los capitales, bienes y servicios procedentes de fuera de la Zona".

Esta idea de dar un tratamiento a los capitales extranjeros se ve ampliada y corroborada en la Declaración de Bogotá (16 de Agosto de 1966); en la Declaraclón de Punta del Este (12-14 de Abril de 1967); en el Consenso de Viña del Mar (Mayo de 1969) y en la Primera Reunión de Ministros de Relaciones Exteriores del Acuerdo de Cartagena en Lima (24 de Noviembre de 1969).

Más tarde, recogiendo estas inquietudes, el Acuerdo de Cartagena establece dos textos jurídicos diferentes que exigen una política común frente a las inversiones extranjeras. Son los artículos 26 y 27 , respectivamente.

"Artículo 26: Los Países Miembros iniciarán inmediatamente un proceso de coordinación de sus planes de desarrollo en sectores especificos y de armonización de sus políticas económicas y sociales, con la mira de llegar a un régimen de planificación conjunta para el desarrollo integrado del área.

Este proceso se cumplirá paralela y coordinadamente con el de formación del mercado subregional, mediante los siguientes mecanismos, entre otros:

d) La armonización de las políticas cambiaria, monetaria, financiera y fiscal, incluyendo el tratamiento a los capitales de la Subregión o de fuera de ella".

"Artículo 27: Antes del 31 de Diciembre de 1970 la Comisión, a propuesta de la Junta, aprobará y someterá a la consideración de los Países Miem- 
bros un régimen común sobre tratamiento a los capitales extranjeros $y$ entre otros, sobre marcas, patentes, licencias 8 regalías.

Los Países Miembros se comprometen a adoptar las providencias que fueren necesarias para poner en práctica este régimen dentro de los seis meses siguientes a su aprobación por la Comisión".

Características Fundamentales del Régimen Común Aprobado en la Decisión 24.

La Decisión 24 trata de una serie de materias, de manera una tanto desordenada. Aparecen normas sobre inversiones extranjeras, comercialización de tecnologías, créditos externos, transformación de empresas extranjeras en mixtas o nacionales, doble tributación, etc.

Para una mejor sistematización de las materias comprendidas en el Régimen Común, hemos creído indispensable enumerar una serie de características importantes, introduciendo en cada una de ellas los artículos pertinentes.

Estas características son:

\section{Es un Régimen Común.}

Se trata de un conjunto de disposiciones comunes para toda la subregión Andina, y que contienen fundamentalmente dos tipos de normas: tratamiento de las inversiones extranjeras y tratamiento de la tecnología extranjera. (Artículo A Transitorio).

\section{Se favorece a las empresas definidas como nacionales 0 mixtas.}

La Decisión 24 persigue que las ventajas derivadas del Acuerdo de Cartagena favorezcan a las empresas definidas como nacionales 0 mixtas.

El artículo 27 del Régimen Común establece que:

"Gozarán de las ventajas derivadas del Programa de Liberación del Acuerdo de Cartagena únicamente los productos producidos por las empresas nacionales y mixtas de los Países Miembros, así como por las empresas extranjeras que se encuentren en vias de transformarse en empresas nacionales o mixtas, en los términos establecidos en el presente Capítulo". Ahora bién, ¿qué se entiende por empresa nacional y mixta?

"Artículo 1: La empresa nacional es la constituída en el país receptor y cuyo capital pertenezca en más del $80 \%$ a inversionistas nacionales siempre que, a juicio del organismo nacional competente, esa proporción se refleje en la dirección técnica, financiera, administrativa y comercial de la empresa".

"Artículo 1: La empresa mixta es la constituída en el país receptor y cuyo capital pertenezca a inversionistas nacionales en una proporción que fluctue entre el $51 \%$ y el $\mathbf{8 0} \%$, siempre que, a juicio del organismo nacional competente, esa proporción se refleje en la dirección técnica, financiera, administrativa y comercial de la empresa".

"Artículo 36: Se considerarán también empresas mixtas aquellas en que 
participan el Estado o empresas del Estado, aunque dicha participación sea inferior al 51\% del capital, siempre que la representación estatal tenga capacidad determinante en las decisiones de la empresa. Corresponderá a la Comisión, a propuesta de la Junta, establecer el porcentaje mínimo de la participación del Estado o de empresas del Estado a que se refiere este artículo, dentro de los 3 meses siguientes a la entrada en vigor del presente régimen".

Precisando aún más el alcance de este artículo, la Decisión № 47 de la Comisión del Acuerơo de Cartagena (Diciembre de 1971) establecío lo siguiente:

"Artículo 1: Se considirarán empresas mixtas aquellas en que participe el Estado, entes para-estatales o empresas del Estado del país receptor en un porcentaje no inferior al $30 \%$ del capital social y siempre que a juicio del ONC (Organismo Nacional Competente, es decir, en Chile, el "Comité de Inversiones Extranjeras de la Corfo"), el Estado tenga capacidad determinante en las decisiones de la empresa.

"Se entiende por capacidad determinante la obligación de que concurra la anuencia de los representantes estatales en las decisiones fundamentales para la marcha de la empresa.

"Para fines de la presente Decisión (la número 47), se entenderá por ente para-estatal o empresa del Estado aquel constituído en el país receptor, cuyo capital pertenezca al Estado en más del $80 \%$ y siempre que éste tenga capacidad determinante en las decisiones de la empresa".

"Artículo 2: Si como consecuencia de la venta de acciones, participaciones o derechos del Estado o de empresas del Estado a otros inversionistas nacionales, dejan de cumplirse los porcentajes señalados en el artículo 1 de la Decisión 24 y de esta Decisión, la empresa respectiva perderá la calidad de mixta. Los productos de tal empresa perderán el derecho a gozar de las ventajas derivadas del Programa de Liberación del Acuerdo de Cartagena, mientras no se convenga con el ONC las condiciones para cumplir el porcentaje de participación de inversionistas nacionales exigido por las disposiciones citadas".

La definición de empresa que dá el Régimen Común, se refiere al "ente receptor de un aporte". Ahora bién, desde ese punto de vista, la paiabra "empresa" puede asumir variadas formas jurídicas: sociedad anónima, sociedad colectiva, sociedad en comandita, etc. Como la Decisión 24 no se pronuncia por ninguna forma en particular de empresa, y, consecuentemente, hay que interpretar ese término en sentičo amplio, cabé perfectamente la posibilidad de aplicar también el Régimen Común no sólo a las sociedades mencionadas, sino que también a otro tipo de entes, tales como las cooperativas, asentamientos, organismos vecinales, etc.

En todo caso, si se trata de sociedades por acciones, el capital deberá estar representado en acciones nominativas. Las acciones al portador actualmente existentes, deberán transformarse en acciones nominativas dentro del plazo de un año contado desde el 30 de junio de 1971. (Artículo 45) 
Como se podrá apreciar, la tarea del ONC es decisiva, por cuanto en definitiva queda entregada a su criterio la calificación de la empresa, al tener que pronunciarse sobre si los porcentajes de capital se reflejan o no en la dirección de las empresas. Como en cada País Andino habrá un ONC diferente, pudiera en el futuro producirse una disparidad de criterios tal, que desvirtúe el sentido de las disposiciones contenidas en la Decisión 24.

III. De la Nacionalización de empresas extranjeras, o de su transformactón en mixtas.

El Régimen Común contempla mecanismos y proceđimientos suficlentemente eficaces para hacer posible una participación creciente del capital nacional en las empresas extranjeras existentes o que se establezcan en los Países Miembros, en tal forma que se llegue a la creación de empresas mixtas en que el capital nacional sea mayoritario y en que los intereses nacionales tengan capacidad para participar en forma determinante en las decisiones fundamentales de dichas empresas.

"Artículo 1: La empresa extranjera es aquella cuyo capital perteneciente a inversionistas nacionales es inferior al $51 \%$ o, cuando siendo superior, a juicio del ONC, ese porcentaje no se refleja en la dirección técnica, financiera, administrativa y comercial de la empresa".

La empresa extranjera así definida, que desee gozar de las ventajas derivadas del programa de liberación del Acuerdo de Cartagena para sus productos, deberá convenir con el ONC del país receptor su transformación en empresa nacional o mixta (Artículo 28).

A contrario sensu, la empresa extranjera que no convenga su transformación, podrá seguir subsistiendo como tal, pero no podrá gozar de las ventajas derivadas del programa de liberación. Deberá conformarse con operar dentro del mercado nacional.

Como ha quedado dicho, el ONC es en Chile el "Comité de Inversiones Extranjeras de la Corfo", como consta del aviso publicado en tal sentido en el Diario Oficial de 20 de enero de 1972 (página 22).

Los convenios sobre transformación de empresas extranjeras en empresas mixtas deben contener las estipulaciones siguientes:

1) El plazo dentro del cual se cumplirá la transformación;

2) La gradualidad del proceso de transferencia de las acciones, participaciones o derechos a favor de inversionistas nacionales;

3) Reglas que aseguren la progresiva participación de los inversionistas nacionales o de sus representantes en la dirección técnica, financiera, administrativa y comercial de la empresa;

4) La forma en que se determinará el valor de las acciones, participaciones o derechos, al tiempo de su venta; y

5) Los sistemas que aseguren el traspaso de las acciones, participaciones o derechos, a inversionistas nacionales. (Artículo 31) 


\section{Gradualidad.}

La Decisión 24 obliga a realizar el proceso de transformación dentro de clertos plazos y modalidades. Es lo que se llama "gradualidad". Para determinar esta gradualidad, hay que distinguir fundamentalmente entre la situación de las empresas extranjeras definidas como "actualmente existentes" en el territorio de cualquier País Miembro, y empresas extranjeras que se establezcan con posterioridad al 30 de junio de 1971. En uno y otro caso las normas de gradualidad son diferentes.

\section{Empresas extranjeras "actualmente" existentes.}

Se entenderá por empresa extranjera actualmente existente aquellas que se encuentren legalmente constituídas en el territorio del país respectivo el 30 de junio de 1971 (Artículo 28 inciso final).

Estas empresas deben convenir con el ONC del país receptor, dentro de los 3 años siguientes al 30 de junio de 1971, su transformación en empresas nacionales o mixtas, en forma gradual y progresiva.

Durante estos tres años, al menos un $15 \%$ del capital de la empresa, debe pertenecer a inversionistas nacionales. (Artículo 28 inciso II).

El plazo dentro del cual deberá operarse dicha transformación no podrá exceder de:

- 15 años, en Colombia, Chile y Perú

- 20 años, en Bolivia y Ecuador, contados a partir del 30 de junio de 1971, en ambos casos.

Al cumplirse los dos tercios del plazo convenido para la transformación deberá haber una participación de inversionistas nacionales en el capital de las mencionadas empresas, no inferior al $45 \%$ de éste.

Sanción para las empresas que no firmen el Convenio.

"Artículo 29: Los organismos nacionales encargados de la expedición de certificados de origen de las mercaderías otorgarán dichos certificados a los productos producidos por las empresas extranjeras actualmente existentes que, dentro del plazo de 3 años antes aludido, expresen formalmente su intención de transformarse en empresas nacionales o mixtas ante el gobierno del país receptor.

"Los productos de las empresas extranjeras actualmente existentes que no celebraren el convenio para transformarse en empresas nacionales o mixtas dentro del mencionado plazo de 3 años, no podrán disfrutar de las ventajas derivadas del programa de liberación del Acuerdo y, en consecuencia, no les será extendido certificado de origen por la autoridad competente".

\section{Gráfico explicativo}

Gradualidad en Colombia, Chile y Perú: 


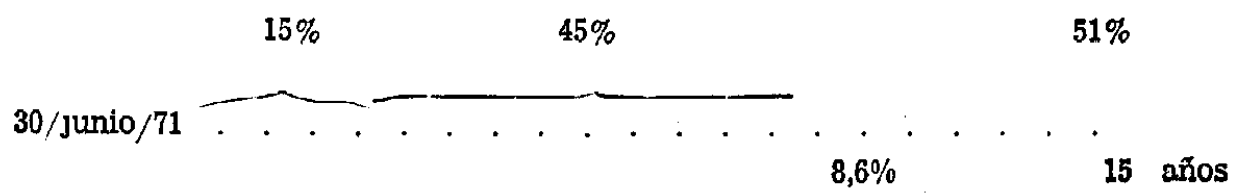

Gradualidad en Ecuador y Bolivia:

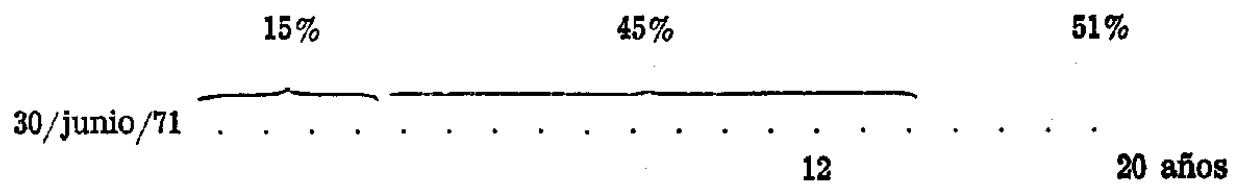

En el ejemplo de Colombia, Chile y Perú, nos hemos puesto en el caso que el Convenio se firmó el 30 de junio de 1973. El plazo máximo que puede convenirse en este caso es de 13 años. (El plazo podría ser maturalmente menor). Durante los tres primeros años de vigencia de la Decisión 24, debe producirse una transformación de capitales igual al $15 \%$. Una vez cumplidos dos tercios del plazo convenido (es decir, 8,6 años, contados desde el 30 de junio de 1973), dicha transferencia debe ser igual a un $45 \%$. Finalmente, al cabo de los 13 años (15 años desde la puosta en vigencia del Régimen Ccmún), la participación de inversionistas nacionales en la empresa de'be ser, al menos, de un $51 \%$ en la propiedad del capital de la empresa.

En el ejemplo de Ecuador y Bolivia, nos hemos puesto en el caso que el Convenio se firmó, al igual que en el ejemplo anterior, dos años después de entrar en vigencia el Régimen Común. En este caso, al finalizar el perícdo de tres años siguientes al 31 de junio de 1971, un 15\% del capital de la empresa, a lo menos, debe estar en manos de inversionistas nacionales. Al cumplirse dos tercios del plazo convenido (que era de 18 años), o sea, a los 12 años, a lo menos un $45 \%$ del capital de la empresa debe estar en manos de nacionales. Finaimente, al cabo de los 18 años (20 años desde la puesta en vigencia del Régimen Común), a lo menos un $51 \%$ de las acciones, participaciones o derechos de la empresa debe estar en manos de inversionistas nacionales de Ecuador 0 Bolivia.

2. Empresas extranjeras que se establezcan en el territorio de cualquier País Miembro a partir del 10 de julio de $19^{\eta} 1$.

Estas empresas deben obligarse, en representacion de sus inversionistas, a poner en venta para ser adquirido por inversionistas nacionales, en forma gradual y progresiva, el porcentaje de sus acciones, participaciones o derechos que sea necesario para que dichas empresas se transformen en empresas mixtas.

En Colombia, Chile y Perú, el plazo de transformación no podrá exceder diz 15 años contados desde la firma del convenio.

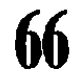


En Bolivia y el Ecuador este plazo no podrá exceder de 20 años. En este caso, el plazo se cuenta después de 2 años de iniciada la producción.

Para determinar los porcentajes de participación que gradualmente se iran entregando a los inversionistas nacionales, hay que distinguir, nuevamente, dos situaciones:

2.1. En el caso de Colombia, Chile y el Perú, el Convenio respectivo deberá estipular una participación de inversionistas nacionales en el capital de la empresa no inferior al 15\% de éste en el momento en que inicie su producción, no inferior al $\mathbf{3 0} \%$ cuando se haya cumplido una tercera parte del plazo convenido $\mathrm{y}$ no inferior al $45 \%$ una vez transcurridos las dos terceras partes del mismo.

2.2. En el caso de Bolivia y el Ecuador, la participación progresiva de inversionistas nacionales en el capital de la empresa deberá ser no menor del $\mathbf{5 \%}$ a los 3 años de iniciada la producción, no inferior al $10 \%$ cuando se haya cumplido una tercera parte del plazo convenido y no inferior al $35 \%$ una vez transcurridos las dos terceras partes del mismo.

Tanto para Colombla, Chile y Perú, como para Ecuador y Bolivia, en el cálculo de los porcentajes señalados antes, se computará como de inversionistas nacionales cuqlquier participación de la Corporación Andina de Fomento. (Inciso IV del Artículo 30). Ampliando el sentido de esta disposición, la Decisión No 48 de la Comisión del Acuerdo de Cartagena (Diciembre de 1971) estableció lo siguiente:

"Artículo 1: Sin menoscabo de lo dispuesto en su Convenio Constitutivo, las inversiones directas de la Corporación Andina de Fomento, una vez cumplidos los trámites de autorización y registro previstos en la Decisión 24, serán considerados como nacionales en cada País Miembro del Acuerdo de Cartagena, para todos los efectos de dicha Decisión.

"Artículo 2: La transferencia de acciones, participaciones o derechos de propiedad de la Corporación Andina de Fomento (CAF) a inversionistas extranjeros se regirá por las condiciones $y$ modalidades establecidas en el artícuio 32 de la Decisión 24".

El primitivo texto del artículo 30 de la Decisión 24, computaba como de inversionistas nacionales "cualquier participación de inversionistas subregionales". (EI inversionista subregional es el nacional de cualquier País Miembro distinto del país receptor. Artículo 1 de la Decisión N: 46). Sin embargo, una decisión posterior, la recién mencionada Decisión № 46 sobre "Empresas Multinacionales" (Diciembre de 1971), modificó la situación de los inversionistas subregionales, de la manera siguiente:

"Artículo 2, inciso II: La Comisión, a propuesta de la Junta, reglamentará el inciso IV del artículo 30 de la Decisión 24 en la referente a la facultad de computar los aportes de inversionistas subregionales como de inversionistas nacionales. Mientras el mencionado reglamento no entre en vi- 
gencia, no se aplicará dicho inciso en lo que respecta a los aportes de inversionistas subregionales".

De esta manera, los inversionistas subregionales se consideran, para todos los efectos, como inversionistas extranjeros, y se sujetan a lo dispuesto en la Decisión 24, salvo en lo que atañe a la participación en una empresa multinacional, en cuyo caso se le aplican normas distintas.

El nuevo criterio de la Comisión del Acuerdo de Cartagena ha sido el de permitir una circulación limitada de capitales subregionales. El capital subregional circulará dentro de la Subregión Andina solamente en la medida que cumpla ciertas funciones de desarrollo integrado, y a través de una empresa mul. tinacional andina.

No puede ignorarse la importancia del nuevo criterio de la Comisión del Acuerdo de Cartagena. Uno de los fundamentos de un mercado común, era la "libre circulación de capitales" dentro de la zona liberada. Este fundamento; en el caso andino, ha quedado fuertemente limitado, lo que demuestra la particularidad' de este proceso. Influye naturalmente en esta nueva perspectiva el hecho de que en el Area Andina, especialmente en Chile y Perú, existe cada vez más una participación del Estado en la propiedad de los bienes de producción.

\section{Gráfico explicativo}

Gradualidad en Colombia, Chile y Perú: $45 \%$

$$
30 \%
$$

$15 \%$

$51 \%$

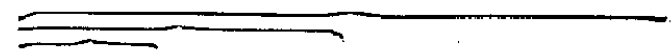

Firma

del

Convenio

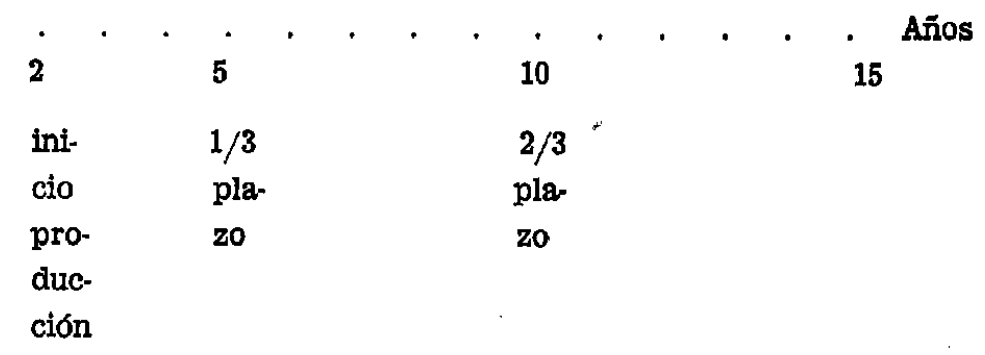


Gradualidad en Bolivia y Ecuador:

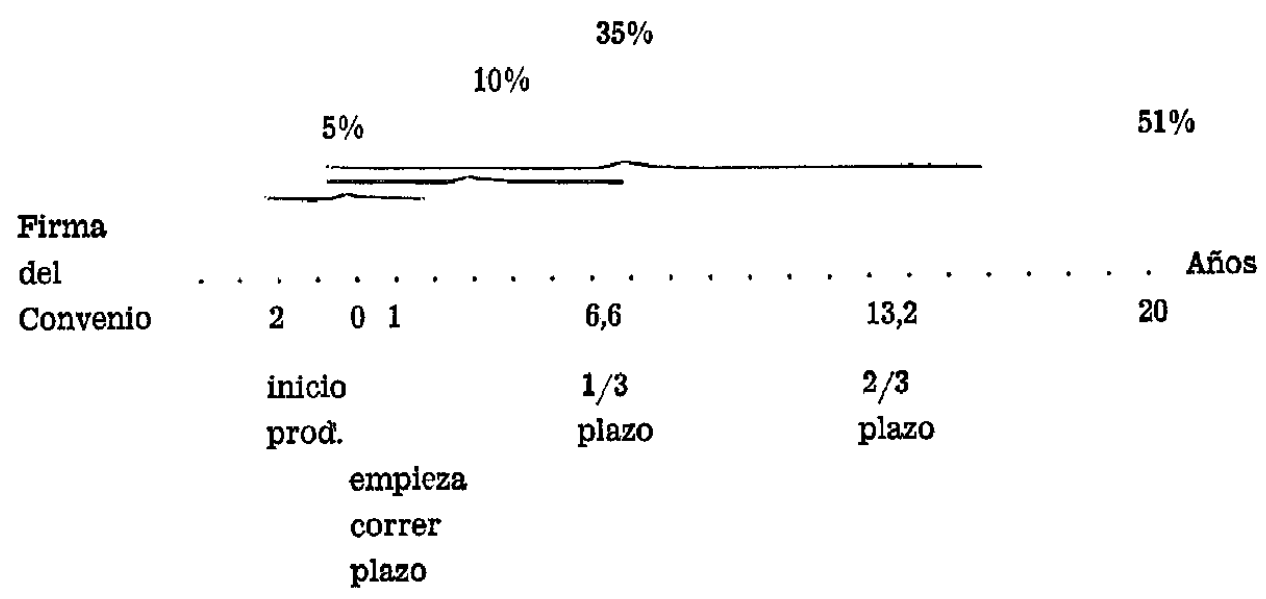

En el ejemplo de Colombia, Chile y Perú. el plazo de 15 años está contado desde la firma del convenio. Hemos supuesto que la producción se inició a los dos años de firmado el Convenio. Al momento de iniciarse la producción, a lo menos el $15 \%$ del capital debe estar en manos de inversionistas nacionales. Ese porcentaje debe ser igual a 30\% al cumplirse el tercio del plazo convenido ( 5 años), e igual al $45 \%$ al cumplirse los dos tercios de dicho plazo (en el ejempio, 10 años). Al cumplirse la totalidad del plazo (15 años), el $51 \%$ de las acciones, participa. ciones o derechos estará en manos de inversionistas nacionales.

En el ejemplo de Bolivia y Ecuador, hemos supuesto que la producción se inicia dos años después de la firma del Convenio. Y como el plazo (que hemos supuesto en el máximo, es decir, 20 años), comienza a contarse dos años después de iniciada la producción, entre la firma del Convenio y la llegada del plazo mediará un total de 24 años. A los tres años de iniciada la producción (es decir, 1 año después de que comienza a correr el plazo), el $5 \%$ del capital de la empresa, a lo menos, deberá estar en manos de inversionistas nacionales. Cuando se ha cumpiido la tercera parte del plazo convenido (6,6 años), el $10 \%$ a 10 menos debe pertenecer a inversionistas nacionales. Finalmente, una vez transcurridas las dos terceras partes del plazo convenido (en nuestro ejemplo, 13,2 añ้os), la participación de inversionistas nacionales en el capital de la empresa extranjera no podrá ser inferior al 35\%. Una vez transcurridos los 20 años, el $51 \%$ del capital de la empresa estará en manos nacionales.

Efectos que produce la firma del Convenio de Transformación.

1. Los productos de las empresas extranjeras gozarán de las ventajas derivadas del programa de liberación del Acuerdo de Cartagena durante el plazo convenido para su transformación en empresas mixtas. (Artículo 32). 
2. Si la empresa dejare de cumplir las obligaciones estipuladas en el respectivo convenio o si al término del plazo pactado no se hubiere efectuado la transformación de la empresa extranjera en empresa mixta, sus productos dejarán de gozær de las ventajas del programa de liberación y, en consecuencia, no podrán ser amparados por certificados de origen. (Artículo 32)

3. La obligación de las empresas extranjeras de poner en venta determina. dos porcentajes de las acciones, participaciones o derechos a que se refieren los artículos 3, 28 y 30 (del Régimen Común) será controlada por el ONC. (Artículo 35)

La obligacićn de poner en venta se cumplirá bien por la venta a los particulares, al estado o a empresas del Estado del país receptor. (Artículo 35)

Para dar cumplimiento a la obïgación de poner en venta, no es suficiente realizar una oferta de venta, sino que es indispensable que sea comprada por un inversionista nacional (Estado, empresas del Estado o particulares). Puedo ocurrir, en efecto, que ningún interesado compre las acciones, participaciones o derechos en venta. En este caso, la empresa extranjera se considerará como incumpliendo su obligación, y perderá el derecho a gozar de las ventajas deri. vačas del Programa de Liberación del Acuerdo. En realidad, si no existe ninguin interesado en la compra de una empresa, ni siquiera el Estado, esto demuestra que aquélla ha dejado de tener prioridad para el desarrollo nacional o subregional, y, en consecuencia, no interesa al legislador el protegerla con las ventajas de! Acuerdo de Cartagena.

\section{Registro y Control de las Inversiones Extranjeras, y de la Tecnología.}

Uno de los obstáculos mayores que ha presentado el tratamiento a las inversiones extranjeras, así como a la comercialización de la tecnologia extranjera, es el desconocimiento que se tiene sobre los beneficios y costos reales de éstos.

Se trata, en consecuencia, de tener una información cabal de los hechos. "El Régimen trata de que, en el futuro, a través de un procedimiento de registro y control, sepamos con claridad qué va a hacer la empresa extranjera, cómo va a actuar, cuáles son los costos de su acción, cuáles son sus beneficios y, mediante evaluaciones objetivas, en qué medida se necesita de inversión extranjera y una transferencia de tecnologías determinadas. Es decir, el Régimen Común crea un sistema administrativo, fundamentalmente informativo, de autorización y registro para poder seguir el curso de los hechos y la vida misma de la empresa extranjera y su funcionamiento en la economía nacional". (Intervención del Dr. Germánico Salgado, en la Conferencia sobre "Modelos Latinoamericanos de Tratamiento a las Inversiones Extranjeras", Hamburgo, 13 de Octubre de 1971).

Para entrar al análisis de las disposiciones sobre registro y control, debemos distinguir dos órdenes de materias: las inversiones extranjeras y la tecnología. 


\section{a) La Inversión Extranjera.}

a.1) La Inversion Extranjera directa son "Ios aportes provenientes del exterior de propiedad de personas naturales o empresas extranjeras, al capital de una empresa, en monedas libremente convertibles, plantas industriales, maquinaria $O$ equipos, con derecho a la reexportación de su valor y a la transferencia de utilidades al exterior". (Artículo 1)

Igualmente se consideran como inversión extranjera directa las inversiones en moneda nacional provenientes de recursos con derecho a ser remitidos al exterior". (Artículo 1)

\section{Análisis de la Definición.}

a) Se trata de aportes de propiedad de personas naturales o de empresas extranjeras. La palabra "extranjeras" es en el artículo 1 de la Decisión 24, ca. lificativa tanto del sustantivo "personas naturales" como del de "empresa". Una interpretación diferente de este texto pođría concluir en una aberración: que las inversiones provenientes del exterior y pertenecientes a personas naturales nacionales, son consideradas como inversión extranjera directa; y que, en cambio, las inversiones provenientes del exterior y pertenecientes a empresas naciomales se consideran como "inversión nacional".

b) El artículo 1 no especifica la naturaleza de la "empresa", por lo que hay que entender ese concepto en su sentidio más amplio de "ente receptor de aportes de capital". En tal sentido, no sólo es empresa la sociedad anónima, la sociedad colectiva civil o comercial, la sociedad en comandita; sino que caen también en la acepción "empresas" las cooperativas. los asentamientos y cualquier otro organismo de esa naturaleza.

c) Con el objeto de evitar los problemas derivados de un avalúo exagerado de la tecnología, así como para evitar el control de la empresa por parte del proveedor de tecnología extranjera, el artículo 1 excluye el aporte de tecnologías

El valor de la tecnología no es reexportable y las utilidades que se perciban por este concepto no son remesables al exterior.

Frecuentemente era muy difícil para los países determinar el valor real de la tecnología aportada, lo que se prestaba para fraudes. Además, las empresas extranjeras continuaban percibiendo utilidades por concepto de tecnologías obsoletas.

El hecho de excluir la tecnología como aporte de capital e inversión extranjera directa, no impide que se pague un precio por dicha tecnología. En efecto, el artículo 21 de la Decisión 24 establece, precisamente, que:

"Las contribuciones tecnológicas intangibles d"arán derecho al pago de regalías, previa autorización del ONC, pero no podrán computarse como aporte de capital. 
Cuando esas contribuciones sean suministradas a una empresa extranjera por su casa matriz o por otra filiar de la misma casa matriz, no se autorizará el pago de regalías ni se admitirá deducción alguna por ese concepto para efectos tributarios".

Con el inciso II del artículo 21 se pretende impedir una duplicidad en la salida de utilidacles. (La duplicidad se producía por la remesa de utilidades y de royalties simultáneamente).

d) Entre los bienes tangibles que pueden formar parte de la inversión extranjera directa, sólo se ha incluido a las plantas industriales; maquinarias y equipos nuevos. Se ha exciuido la maquinaria reacondicionada, porque resulta de difícil avalúo.

e) Tampoco se incluye dentro de la definición de inversión extranjera directa a los créditos extranjeros.

El crédito extranjero, público o privado, está también sometido a normas estrictas de autorización y control.

"Los créditos externos que contrate una empresa requieren autorización previa del organismo competente y deben ser registrados ante el mismo".

"Se podrán autorizar límites globales de endeudamiento externo por periodos determinados. Los contratos de crédito celebrados dentro de los límites globales autorizados, deberán ser registrados ante el organismo competente". (Artículo 14)

"Los Gobiernos de los Países Miembros se abstendrán de avalar o garantizar en cualquier forma, ya sea directamente o por intermedio de instituciones oficíales o semioficiales, operaciones de crédito externo celebradas por empresas extranjeras en que no participe el Estado". (Artículo 15)

La palabra "crédito" está tomada en estos asuntos en el sentido de préstamo o mutuo.

f) El inciso II de la definición de inversión extranjera directa habla de "las inversiones en moneda nacional provenientes de recursos con derecho a ser remitidos al exterior". Estos "recursos" no son otra cosa que las utilidades que produce una determinada inversión extranjera directa, utilidades que bien pueden aplicarse a la misma empresa $o$ actividad" inicial, y entonces se tratara de una "reinversión de utilidades"; o bien pueden aplicarse a una actividad diferente, y entonces sí que estamos en presencia de "inversiones en moneda nacional provenientes de recursos con derecho a ser remitidos al exterior".

En todo caso ambas categorías se consideran como inversiones nuevas sometidas a la obligación de registro y control.

Se entiende por reinversión, "la inversión de todo o parte de las utilidades no distribuidas provenientes de una inversión extranjera directa en la misma em. presa que las haya generado". (Artículo 1)

"La reinversión de las utilidades percibidas por las empresas extranjeras será considerada como una inversión nueva y no podrá hacerse sin previa autorización y registro". (Artículo 12) 
"Los gobiernos de los Países Miembros podrán admitir la reinversión de las utilidades percibidas por la empresa extranjera. sin necesidad de autorización particular, hasta un monto que no exceda anualmente el $5 \%$ del capital de ia empresa respectiva. En estos casos subsiste la obligación de registro". (Artícu10 13)

El artículo 12 no es claro en su interpretación. Hay en él dos términos que se prestan a ambiguiedades: la palabra "percibidas" y, las palabras "empresas extranjeras".

El artículo 1 de la Decisión 24 le da a la expresión "empresas extranjeras" una acepción muy precisa: aquella cuyo capital perteneciente a inversionistas nacionales es inferior al $51 \%$ o, cuando siendo superior, a juicio del ONC, ese porcentaje no se refleja en la dirección técnica, financiera, administrativa y comercial de la empresa. No parece probable que sea éste el sentido en el artículo 12.

Si en el artículo 12 las palabras "empresas extranjeras" estuvieran utilizadas en la acepción del artículo 1, esto significaría marginar de la posibilidad de reinvertir utilidades a los propietarios de una inversión extranjera directa, término este último que está también precisamente definido y diferenciado del de "empresa extramjera" en el Régimen Común. Esto resultaría absurdo, por cuanto el artículo 12 sobre la reinversión de utilidades está colocađo precisamente dentro de un conjunto de tratamientos al inversionista extranjero, y no a la empresa extranjera definida en el artículo 1. Además, de seguirse la interpretación en análisis, se caería en el absurdo de excluir del beneficio de la reinversión a las empresas definidas como mixtas y nacionales, puesto que el artícuio 12 no las menciona en absoluto. $Y$ excluir a las empresas mixtas y nacionales puede tener la peligrosa consecuencia de impedirles lo posibilidaớ de reinvertir en el pafs, lo que constituye también una aberración, por cuanto se trata precisamente de las empresas que se quiere fomentar.

Todo indica, en consecuencia, que cuando el artículo 12 habla de "empresas extranjeras" se ha querido referir a los "inversionistas extranjeros", que son "Ios propietarios de una inversión extranjera directa". (Artículo 1). Lamentablemente se refiere a un solo tipo de inversionista extranjero: las empresas extranjeras, y omite a las personas nacionales extranjeras.

Asi interpretado el artículo 12, presenta aún un problema: el alcance de la palabra "percibir". Por definición la Inversión Extranjera Directa es un aporte proveniente del exterior, $y$, en consecuencia, la "percepción" de la utilidad no se produce sino cuando la utilidad es remesada al exterior. Como el artículo 12 habla sólo de la reinversión de las utilidades "percibidas", podría interpretarse como que no existiría problema para reinvertir las utilidades "devengadas en el pals" (o sea, las no remesadas aún al exterior), sin considerarlas como inversión nueva.

Parece obvio, sin embargo, que la intención del legislador comunitario ha sido la de someter a control todo tipo de reinversiones, percibidas y devengadas, y en tal sentido debería operarse una reforma a la redacción actual del artículo 12. 
En cuanto al artículo 13, caben hacer los mismos comentarios señalados anterjormente.

a.2) En oposición al concepto de "inversión extranjera directa" tenemos el de "inversión nacional". El Régimen Común no la define sino por exclusión. El artículo 1 define, sin embargo, to que es un inversionista nacional: el Estado, las personas naturales nacionales, las personas jurídicas nacionales que no persigan fin de lucro y las empresas nacionales definidas en el artículo 1.

Se considerarán también como inversionistas nacionales a las personas naturales extranjeras con residencia ininterrumpida en el país receptor NO INFERIOR A 1 AÑO, que renuncien ante el ONC el derecho de reexportar el capital y a transferir utilidades al exterior. (Artículo 1)

a.3) El Régimen Común establece una serie de obligaciones y derechos para el inversionista extranjero. Entre las primeras cabe señalar las obligaciones de registro y control de las inversiones. El procedimiento a seguir, para dar cumplimiento a estas obligaciones es el siguiente:

a.3.1) Solicitud: Todo inversionista extranjero que desee invertir en alguno de los Países Miembros deberá presentar su solicitud ante el ONC (en Chile, el Comité de Inversiones Extranjeras de la CORFO) el cual. previa evaluación, la autorizará cuando corresponda a las prioridades del desarrollo del país receptor. (Artículo 2)

Sin perjuicio de las exigencias que cada País Miembro imponga en este sentico, la solicitud de inversión deberá atenerse a la siguiente pauta (Anexo No 1 a la Decisión 24):

\section{Individualización del inversionista.}
a) Nombre o razón social;
b) Nacionalidad;
c) Constitución del Directorio;
d) Composición del personal y Gerencia;
e) Actividad económica;
f) Copia de la escritura social.

\section{Modalidades de la inversión.}

a) Recursos financieros en divisas o créditos;

- moneda en que se efectúa la inversión

- capital de origen nacional

- capital de origen extranjero

- crédito de casa matriz

- crédito de otras fuentes

- interés efectivo a pagarse por los créditos 
b) Recursos físicos o tangibles como:

- plantas industriales

- maquinarias nuevas y reacondicionadas

- repuestos

- equipos nuevos y reacondicionadios

- partes y piezas

- materias primas

- productos intermedios

c) Recursos derivados de la tecnología o intangibles como:

- marcas

- modelos industriales

- capaciơad gerencial

- conocimientos técnicos patentados o mo patentados

- posibles tecnologías alternativas

Los conocimientos técnicos pueden presentarse en las siguientes formas:

i) Objetos:

- muestrarios

- modelos no registrados

- máquinas, aparatos, piezas, herramientas

- dispositivos de confección.

ii) Documentos técnicos:

- fórmulas, cálculos

- planos, dibujos

- inventos no patentados.

iii) Instrucciones:

- notas de elaboración, fabricación, funcionamiento del producto o del proceso

- explicaciones o consejos prácticos de ejecución

- folletos técnicos

- explicaciones complementarias de patentes

- circuitos de fabricación

- métodos de contro1

- montos a pagarse por concepto de regalías

- individualización del perceptor de regalías.

\section{Requerimientos que se satisfacen.}

a) Escasez de ahorro interno;

b) Escasez de divisas;

c) Falta de capacidad directiva o administrativa;

d) Necesidad de acceso a conocimientos tecnológicos escasos;

e) Ausencia de capacidad o de contactos comerciales para la venta de mercaderías en los mercados internacionales; 
f) Falta de espíritu empresarial local.

IV. Plan de participación nacional progresiva:

a) Porcentaje de acciones a colocarse en manos de inversionistas nacionales;

b) Plazo y condiciones para llevarlo a efecto;

c) Forma de determinar el valor de cada colocación.

v. Efectos de la nueva inversión:

a) Fecha aproximađa de iniciación de operaciones normales;

b) Capacidad de operación;

c) Producción exportable;

d) Empleo adicional generado;

e) Importación de materias primas o productos intermedios en producción anual;

f) Utilización de insumos nacionales.

El ONC deberá examinar la solicitud de inversión, y si constata que aquella no corresponde a las prioridades del desarrollo del país, la rechazará, Es una cuestión de hecho que queda enteramente entregada al criterio del ONC.

Por otra parte, es digno de destacarse que "el peso de la prueba" recae sobre el inversionista extranjero. Esto resulta particularmente evidente con el numeral III) de la Pauta, en que al solicitante se le exige demostrar que la inversión satisfacerá, y dará solución relativa, a problemas tales como la escasez de ahorro interno, la escasez de divisas, la falta de capacidad directiva o administrativa, etc. Se comprenderá cuán difícil resultan de ponderar todos estos factores.

a.3.2) Autorización, Prohibición de autorizar y excepcioncs: Como se ha señaiado antes, el ONC tiene amplio margen para aprobar o rechazar una solicitud de inversión extranjera directa. Mas aún, el artículo 3 inciso I agrega que "los Países Miembros no autorizarán inversión extranjera directa en actividades que consideren adecuadamente atendidas por empresas existentes". Los términos "adecuadamente atendidas" son lo suficientemente ambiguios como para ampliar el margen de acción del ONC, en orden a otorgar o rechazar la autorización.

Hay un caso, sin embargo, en que el ONC debe rechazar la solicitud de inversión. Es el contemplado en el inciso II del artículo 3:

"Tampoco autorizarán inversión extranjera directa destinada a la ađiquisición de acciones, participaciones, o derechos de propiedad de inversionistas nacionales".

Esta norma tiene dos excepciones:

Primera Excepción: Las inversiones extranjeras directas que hagan en una empresa nacional para evitar su quiebra inminente, siempre que se cumplan las siguientes condiciones:

a) Que la Superintendencia de Sociedades Anónimas, Compañias de Seguros y Bolsas de Comercio, comprueben la inminencia de la quiebra. 
El juicio de quiebra tiene por objeto realizar en un solo procedimiento los bienes de una persona natural o jurídica, sea o no comerciante, a fin de proveer al pago de sus deudas en los casos y en la forma determinadas por la ley. (Artículo 1 Ley de Quiebras). Una vez declarada la quiebra, ésta produce para el fallido y todos sus acreedores un estado indivisible. Comprenderá, en consecuencia, todos los bienes de aquél y todas sus obligaciones, aun cuando no sean de plazo vencido, salvo aquellos bienes y obligaciones que la ley expresamente exceptúe. (Artículo Ley de Quiebras).

Cualquiera de los acreedores podrá solicitar la declaración de quiebra, aun cuando su crédito no sea exigible, en los siguientes casos (artículo 37 de la Ley de Quiebras).

1) Cuanđo el deudor comerciante cese en el pago de una obligación mercantil;

2) Cuando el deudor contra el cual existieren tres o más títulos ejecutivos $\mathrm{y}$ vencidos, provenientes de obligaciones diversas, y estuvieren iniciadas, a lo menos, dos ejecuciones, no hubiere presentado en todas éstas, dentro de los cuatro días siguientes a los respectivos requerimientos, bienes bastantes para responder a la prestación que adeude y las costas;

3) Cuando el deudor se fuge del territorio de la República o se oculte dejando cerradas sus oficinas o establecimientos, sin haber nombrado persona que administre sus bienes, y dé cumplimiento a sus obligaciones. En este caso podrá también solicitar la deciaración de quiebra, el respectivo sindico o delegado, $y$

4) Cuando el deudor haya celebrado un convenio extrajudicial con sus acreedores y éste sea declarado nulo o resuelto, sin perjuicio del derecho de ins acreedores por obligaciones no comprendidas en el convenio.

El Régimen Común no habla de "Quiebra", sino de "inminencia de quiebra". Este us un concepto diferente, que deberá apreciar en el hecho la Superintendencia de Sociedades Anónimas. Esta última deberá analizar si existen o no las causales que autorizan a pedir la declaración de quiebra. En caso afirmativo estaremos en presencia de una "quiebra inminente".

b) Que la empresa acredite haber otorgado opción de compra preferente a inversionistas nacionales o subregionales, y

c) Que el inversionista extranjero se comprometa a poner en venta las acciones, participaciones o derechos que adquiera en la empresa, para su compra por inversionistas nacionales en el porcentaje necesario para constituir una empresa nacional en un plazo que no exceda de 15 años y que se fijará en cada caso de acuerdo con las características del sector. La autorización expedida por el ONC contendrá el plazo y las condiciones en que se cumplirá dicha obligación, la forma en que se determinará el valor de las acciones, participaciones o derechos a! tiempo de su venta y, si fuere el caso, los sistemas que aseguren el traspaso de éstas a inversionistas nacionales.

Segunda Excepción: Podrá autorizarse la participación de inversionistas extranjeros en empresas nacionales o mixtas siempre que se trate de la ampliación 
del capital de la empresa respectiva y que esa participación no modifique la calidad de nacional o mixta de ésta. (Artículo 4).

a.3.3) Registro de la inversión extranjera directa: "Toda inversión extranjera directa se registrará ante el ONC junto con el convenio en que se determinen las conđiciones de la autorización. \$l monto de la inversión se registrará en moneda ulbremente convertible". (Artículo 5).

Las inversiones extranjeras existentes en el territorio nacional al $\mathbf{3 0}$ de Junio de 1971 deberá registrarse ante el Comité de Inversiones Extranjeras de la Corfo dentro de los seis meses siguientes. (Artículo B) Transitorio, inciso primero).

a.3.4) Control de la inversión extranjera directa: "El control del cumplimiento de las obligaciones contraidas por los inversionistas extranjeros estará a cargo del organismo que registra la inversión, en coordinación con las reparticiones o dependencias estatales competentes en cada caso". (Artículo 6 inciso I).

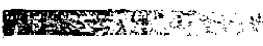

\section{un... b) La Tecnología}

Hemos visto antes que las contribuciones tecnológicas intangibles (que la "Pauta" para la autorización, registro y control de la inversión extranjera señala: marcas, modelos industriales, capaciđad gerencial, conocimientos técnicos pateniados o no patentados, posibles tecnologías alternativas) no se consideran inversión extranjera directa, ni aportes de capital, pero dan derecho al pago de regalías, previa autorización del ONC. (Artículo 21).

Además, y al igual que la inversión extranjera directa, la tecnologia intangible (la palabra "intangible" se opone a "tangible", que son las plantas industriales, las maquinarias nuevas y reacondicionadas, equipos nuevos y reacondicionados, repuestos, partes y piezas, materias primas y productos intermedios) debe ser autorizada.

b.1) Autorización de los contratos sobre importación de tecnología y sobre patentes y marcas.

Todo contrato sobre importación de tecnología y sobre patentes y marcas deberá ser examinado y sometido a la aprobación del ONC, el cual deberá evaluar ia contribución efectiva de la tecnología importada mediante la estimación de sus utilidades probables, el precio de los bienes que incorporen tecnología u otras iormas especificas de cuantificación del efecto de la tecnología importada. (Ar(f́culo 18)

Esta evaluación tiene por objeto evitar los abusos que en el pasado realizaron los proveedores de tecnología, en orden a vender tecnología obsoleta 0 a precios exageradamente altos.

b.2) Cláusulas prohibidas en los contratos de transferencia tecnológica.

Los Países Miembros no autorizarán la celebración de contratos sobre transferencia de tecnología externa o patentes que contengan: 
1. Cláusulas de amarre.-Cláusulas en virtud de las cuales el suministro de tecnología lleve consigo la obligación, para el país o la empresa receptora, de adquirir de una fuente determinada bienes de capital, productos intermeđiios, materias primas $\mathrm{u}$ otras tecnologías o de utilizar permanentemente personal señalado por la empresa provecdora de tecnología.

Excepción: En casos especiales el país receptor podrá aceptar cláusulas de esta naturaleza para la adquisición de bienes de capital, productos intermedios o materias primas, siempre que su precio corresponda a los niveles corrientes en el mercado internacional.

2. Cláusulas conforme a las cuales la empresa vendedora de tecnología se reserve el derecho de fijar los precios de venta o reventa de los productos que se elaboren con base en la tecnología respectiva.

3. Cláusulas que contengan restricciones referentes al volumen y estrunturade la producción.

4. Cláusulas que prohiben el uso de tecnologías competidoras;

5. Cláusulas que establezcan opción de compra, total o parcial, en favor del proveedor de la tecnología.

6. Cláusulas que obliguen al comprador de tecnología a transferir al proveedor los inventos o mejoras que se obtengan en virtud del uso de dicha tecnología.

7. Cláusulas que obliguen a pagar regalías a los titulares de las patentes por pstentes no utilizadas.

8. Otras cláusulas de efecto equivalente.

9. Cláusulas en que se prohiba o limite de cualquier manera la exportación de los productos elaborados a base die la tecnología respectiva.

Excepcionalmente, y en casos debiciamente calificados por el ONC, podrá admitirse este tipo de clíusılas. Pero, $€ n$ ningún caso se admitirán cláusulas de esta naturaleza en relación con el intercambio subregional o para la exportación de productos similares a terceros países.

10. Cláusulas que sustraigan los posibles conflictos o controversias de la jurisdicción o competencia nacionales del país receptor o que permitan la subrogación por los Estados de los derechos y acciones de sus nacionales inversionistas.

Las prohibiciones antes señaladias no distinguen entre tecnología subregional y tecnologías extranjera, por lo que a las primeras se les aplican las mismas normas.

La Comisión, a propuesta de la Junta, podrá señalar procesos de producción, productos 0 grupos de productos respecto de los cuales no se podrá decidir sobre el tratamiento de los privilegios ya concedidos. (Artículo 26)

b.3) Cláusulas prohibidas en los contrates de licencia para la explotación de marcas de origen extranjero (derecho a usar un nombre) (Artículo 25) 
La marca es todo signo especial y características que sirva para distinguir los productos de una industria, los objetos de un comercio o una empresa cualquiera.

La marca puede consistir en una palabra, locución o frase de fantasfa, en una cifra, letra, monograma, timbre, sello, viñeta, franja, emblema, figura, fotografía o dibujo, o en una combinación de estos diversos signos con cierto carácter de novedad. (Decreto-Ley 958 de 1931).

Los contratos de licencia para la explotación de marcas de origen extranjero en el territorio de los Países Miembros no podrán contener cláusulas restrictivas tales como:

1. Prchibición o limitación de exportar o venđer en determinados pá́ses los productos elaborados al amparo de la marca respectiva, o productos similares.

2. Obligación de utilizar materias primas, bienes intermedios y equipos suministrados por el titular de la marca o de sus afiliados. En casos excepcionales, el país receptor podrá aceptar cláusulas de esta naturaleza siempre que el precio de los mismos corresponda a los niveles corrientes en el mercado internacional.

3. Fijación de precios de venta o reventa de los productos elaborados al amparo de la marca.

4. Obligación de pagar regalías al titular de la marca por marcas no utilizadas.

5. Obligación de utilizar permanentemente personal suministrado o señalado por el titular de la marca, y

6. Otras de efecto equivalente.

b.4) Cláusulas obligatorias en los contratos sobre importación de tecnologia (Artículo 19)

Los contratos sobre importación de tecnología deberán contener, por lo menos, cláusulas sobre las materias siguientes:

1. Identificación de las modalidades que revista la transferencia de la tecnología que importa.

2. Valor contractual de cada uno de los elementos involucrados en la transferencia de tecnologia, expresada en forma similar a la utilizada en el registro de la inversión extranjera directa, y

3. Determinación del plazo de vigencia.

b.5) Reglamento para la aplicación de las normas sobre propiedad industrial.

En virtud" del Artículo Transitorio 6), "dentro de los seis meses siguientes a la entrada en vigor del presente régimen, la Comisión, a propuesta de la Junta, adoptará un reglamento para la aplicación de las normas sobre propiedad industrial que comprenderá, entre otros, los siguientes temas" (Anexo No 2 de la Decisión 24):

1. Determinación de los signos, palabras, símbolos o nombres que se pueden registrar como marcas; 
2. Disposiciones sobre propiedad de la marca, procedimientos para adquirirla, personas que pueden ser titulares del derecho, etc.;

3. Clasificación uniforme de los productos para los efectos de las marcas;

4. Publicación y términos de oposición al registro;

5. Prioridad o derecho a oposición;

6. Uso del privilegio;

7. Caducidad por falta de uso;

8. Término del privilegio;

9. Negociación de la marca;

10. Causales uniformes sobre nulidad, falta de renovación, cancelación por registros anteriores, etc.;

11. Clasificación de patentes;

12. Determinación de los productos y procesos industriales que puedan ser patentados en función de los objetivos de la estrategia global para el desarrollo de la subregión;

13. Condiciones de patentabilidad y particularmente, criterios uniformes para establecer la novedad y la aplicación industrial de la patente;

14. Titulares de la patente;

15. Procedimiento para el registro, la oposición, la forma para poner en práctica la invención, etc.;

16. Término del privilegio, $\mathbf{y}$

17. Normas sobre modelos y dibujos industriales.

En Diciembre de 1971, la Junta del Acuerdo de Cartagena sometió a la consideración de la Comisión de dicho Acuerdo, una Propuesta de Decisión (la número 19) relativa al "Reglamento para la aplicación de las normas sobre Propiedad Industrial". En esa oportunidad no hubo acuerdo para adoptar la Decisión respectiva, y se convino que el tema fuera considerado en una próxima reunión (a celebrarse en el mes de Mayo de 1972).

b.6) Registro

"Artículo E) Transitorio: Todos los contratos sobre imputación de tecnología y sobre licencias para la explotación de marcas o patentes de origen extranjero, celebrados hasta la fecha de entrada en rigor del presente régimen; deberán ser registrados ante el ONC dentro de los seis meses siguientes a dicha fecha".

\section{Derechos y Obligaciones del Inversionista Extranjero.}

El Régimen Común establece con claridad los derechos y obligaciones del inversionista extranjero, y se les dá estabilidad jurídica. Los derechos son máximos, y las obligaciones, mínimas.

\section{A. Los Derechos del Inversionista Extranjero.}

El artículo 33 de la Decisión 24 establece que "dentro de las materias comprendidas en el presente régimen los derechos en él consagrados para las em- 
presas extranjeras y mixtas son los máximos que les podrán ser otorgados por los Paises Miembros". Por analogía cabe extender esta limitación a los inversionistas extranjeros.

Si bien el artículo 33 está inserto en el Capítulo II de la Decisión 24, que trata de la transformación de las empresas extranjeras en nacionales o mixtas, y no se refiere de una manera explícita al inversionista extranjero, estimamos que ciicho artículo es de aplicación general. En efecto, el espiritu mismo del Régimen Común es precisamente el de señalar con precisión una serie de derechos y beneficios que deben otorgarse al inversionista extranjero. Este espíritu del legislador comunitario se ve claramente expuesto en la Declaración que antecede al articulado de la Decisión 24:

"La Comisión del Acuerdo de Cartagena, Declara:

3. Las normas del régimen común deben ser claras en la formulación de los derechos y obligaciones de los inversionistas extranjeros y de las garantías de que la inversión extranjera estará rodeada en la Subregión. Ađđemás, deben ser suficientemente estables para beneficio reciproco de los inversionistas y de los Paises Miembros".

Por otra parte, existe un artículo bastante más explícito, y que corrobora lo expuesto. Es el Artículo B) Transitorio, inciso II:

"Estas inversiones (las extranjeras existentes en el territorio de los Países Miembros al 30 de junio de 1971) seguirán gozando de los beneficios que les otorgan las disposiciones vigentes en todo lo quer no sea contrario al presente régimen".

Podría respondérseme que en la limitación del artículo B) Transitorio inciso II, están excluidas las "inversiones nuevas" (que están definidas como "las que se realizan con posterioridad al $1^{\circ}$ de julio de 1971, ya sea en empresas existentes o en empresas nuevas". Artículo 1 inciso 9). Pero esta última interpretación c8recería de toda lógica juridica. En efecto, si se limitan los derechos en las inversiones ya existentes, con mayor razón aún la limitación es extensiva a las inversiones que hayan de llegar.

Nuestra interpretación se ve confirmada por el artículo $H$ ) Transitorio, que st bien trata de las leyes de fomento industrial, puede perfectamente ilustrar el espíritu del Régimen Común:

"Los Países Miembros se comprometen a no establecer incentivos a la inversión extranjera diferentes a los contemplados en sus legislacionez de fomento industrial a la fecha de entrada en vigor del presente régimen, mientras no se cumpla el compromiso previsto en el artículo 28 inciso II del Acuerdo de Cartagena sobre armonización de las legislaciones de Fomento Industrial".

Con lo dicho queda en claro que los derechos que la Decisión 24 otorga al inversionista extranjero, son los máximos que les pueden ser otorgados por los Países Miembros. Todo otro derecho o b€neficio, debe entenderse derogado.

Esos derechos son los siguientes: 
1. Derecho a reexportar el capital invertido cuando venda sus acciones, participaciones o derechos a inversionistas nacionales o cuando se produzca la liquidación de la empresa. (Artículo 7 inciso I).

La venta de acciones, participaciones o derechos de un inversionista extranjero a otro inversionista extranjero deberá ser previamente autorizada por el ONC y no se considerará como reexportación de capital. (Artículo 7 inciso II). Essto ültimo, en atención al hecho que no habiendo habido propiamente una nacionalización de la empresa, y continuando ésta en manos extranjeras, no se justifica la remesa de capital. De lo contrario, habría que aceptar las reexportaciones de capital tantas veces cuantas se vendieran las acciones, participaciones o derechos.

"Artículo 8: Se entiende por capital reexportable el formado por el monto de la inversión extranjera directa inicial registrada y efectivamente realizada, más las reinversiones efectuadas en la misma empresa conforme a lo dispuesto en el presente régimen y menos las pérdidas netas, si las hubiere".

Para poder realizar los cálculos actuariales correspondientes, será conveniente llevar contabilidad en moneda extranjera, que permita una exacta evaluación del capital invertido. Para ello, habrá que conformarse a las normas que en esta materia nos dá el Código Tributario:

"Artículo 18: Para todos los efectos tributarios, los contribuyentes, cualquiera que sea la moneda en que tengan pagado o expresado su capital, llevarán contabilidad, presentarán sus declaraciones y pagarán los impuestos que correspondan, en moneda nacional.

"No obstante, la Dirección Regional podrá єxigir el pago de los impuestos en la misma moneda en que se obtengan las rentas o se realicen las respectivas operaciones gravadas.

"En casos calificados, cuando el capital de una empresa se haya aportado en moneda extranjera o la mayor parte de su movimiento sea en esa moneda, el Director Regional podrá autorizar que se lleve la contabilidad en la misma moneda, siempre que con ello no se disminuya o desvirtúe la base sobre la cual deban pagarso los impuestos".

"Artículo 19: Sin perjuicio de otras disposiciones de este Código y de lo dispuesto en leyes especiales, los aportes o internaciones de capitales extranjeros expresados en moneda extranjera se contabilizarán de acuerdo con las reglas siguientes:

“19) Tratándose de aportes o internaciones de capitales extranjeros monetarios o en divisas, la conversión se hará al tipo de cambio en que efectivamente se liquiden o, en su defecto y mientras ello no ocurra, por el valor medio que les haya correspondido en el mercado en el mes anterior al del ingreso.

“29) En el caso de aportes o internaciones de capitales en bienes corporales, su valor se fijará de acuerdo con el precio de mayorista que le 
corresponda en el puerto de ingreso, una vez nacionalizados.

"Para estos efectos, toda diferencia efectiva de valor que se contabilice afectará los resultados dél ejercicio respectivo".

El número $1^{\circ}$ del artículo 19 del Código Tributario, debe entenderse sin perjuicio de lo indicado por el artículo 11 de la Decisión 24, que establece que:

"La conversión de las sumas que tenga derecho a remitir al exterior un inversionista extranjero se realizará al tipo de cambio vigente en el momento de efectuarse el giro.

En los casos en que hubiere participación de inversionistas nactonales, el capital que puede reexportar el inversionista extranjero debe entenderse limitado al porcentaje de su inversión extranjera directa, en lo que dice relación con las reinversiones efectuadas $\mathrm{y}$ con las pérdidas netas. (Artículo 8 inciso II)

2. Derecho a transferir al exterior las ganancias de capital, previo el pago de los impuestos correspondientes.

Se entiende por "ganancia de capital" la diferencia resultante entre el valor real de los activos netos y el capital reexportable (definido anteriormente, Artículo 8), en el caso de liquidación de la empresa. (Artículo 9).

3. Derecho a transferir al exterior las sumas que obtenga como consecuencia de la venta de sus acciones, participaciones o derechos, previo pago de los impuestos correspondientes. (Artículo 10).

Naturalmente que, para que el Régimen Común sea verdaderamente "común", será indispensable armonizar las políticas y legislaciones tributarias, ya que por la vía de los impuestos pudieran resultar cantidades disímiles a reexportar, para una misma cantidad de inversión extranjera directa. Asf, si los tributos son más altos en Colombia que en Perú, el inversionista extranjero se inclinará a invertir en Perú, puesto que dicho país le permite un mayor margen de reexportación de sus capitales.

En nuestro pais, y en virtud del artículo 17 de la Ley de la Renta, el mayor valor que se obtenga en la enajenación de acciones de sociedades anónimas no constituye renta, cuando la operación no se realiza en forma habitual.

4. Derecho a transferir al exterior laś sumas necesarias, por concepto de amortización e intereses, por el uso del crédito externo, en los términos del contrato registrado. (Artículo 16 inciso I).

Como se vió anteriormente, los créditos externos que contrate una empresa requieren autorización previa del ONC y deben ser registrados ante el mismo. (Artículo 14).

Para los contratos de crédito externo convenidos entre casa matriz y riliales o entre filiales de una misma empresa extranjera, la tasa de interés efectivo anual no podrá exceder en más de 3 puntos la tasa de interés de los valores de primera clase vigentes en el mercado fimanciero del país de origen de la moneda en que se haya registrado la operación. Con esto se persigue evitar posibles fraudes. En efecto, pođrían pactarse tasas de interés "exageradas", con el fin de poder 
remesar más sumas por este concepto. De esta manera, y limitando la posibilidad de aumento a 3 puntos en la tasa de interés, desaparece el peligro de posibles fraudes. (Artículo 16 inciso II).

Para los contratos de crédito externo distintos del señalado anteriormente, la tasa de interés efectivo anual que paguen las empresas será determinada por el ONC, debiendo estar estrechamente relacionada con las condiciones prevalecientes en el mercado financiero del país en que se haya registrado la operación. (Artículo 16 inciso II).

Para los efectos de lo dicho anteriormente, se entiende por interés efectivo el costo total que debe pagar el deudor por la utilización del crédito, incluyendo comisiones y gastos de todo orden.

5. Derecho al uso de crédito interno de corto plazo, en los términos y condiciones que fije el reglamento que sobre esta materia dicte la Comisión, a propuesta de la Junta.

Las empresas extranjeras no tienen derecho al crédito interno de largo plazo. (Artículo 17).

La limitación anterior, tiene por objeto favorecer con el ahorro interno sólo a los inversionistas nacionales. Se desvirtuaría la razón misma de la presencia de capitales extranjeros en la Zona, si éstos tuvieran que abastecerse con el esfuerzo nacional. Distinta situación se presenta respecto de los créditos internas de corto plazo. En efecto, puede ocurrir, por ejemplo, que debido a un déficit de caja momentáneo, una empresa extranjera se vea en la imposibilidad de pagar los salarios de sus obreros en una semana determinada. En este caso, aquélla podrá acudir al Banco del Estado y solicitar un préstamo por algunos días, para pagar lo adeudado.

6. Derecho a reinvertir las utilidades percibidas, sin necesidad de una autorización particular, hasta un monto que no exceđa anualmente el $\mathbf{5} \%$ del capital de la empresa respectiva. (Artículo 13).

Este derecho ya fué analizado antes. Cabe agregar que, en todo caso, es facultativo para los Gobiernos de los Países Miembros el admitir o no esta reinversión, toda vez que el artículo 13 habla de "podrán admitir..." Además, en estos casos subsiste la obligación de registro.

7. Derecho a remesar sumas por concepto de pago de regalías, previa autorización del ONC, con ocasión de las contribuciones tecnológicas intangibies. (Artículo 21).

Cuando esas contribuciones sean suministradas a una empresa extranjera por su casa matriz o por otra filial de la misma casa matriz, no se autorizará el pago de regalías ni se admitirá deducción alguna por ese concepto para efectos tributarios. (Artículo 21 inciso II).

8. Derecho, previa autorización del ONC, a transferir al exterior, en divisas libremente convertibles, las utilidades netas comprobadas que provengan de la inversión extranjera directa, sin pasar del $14 \%$ anual de la misma. 
En casos especiales la Comisión, a petición de cualquier País Miembro, po. drá autorizar porcentajes superiores al establecido antes. (Artículo 37).

\section{B. Las Obligaciones del Inversionista Extranjero.}

La Decisión 24 establece una serie de obligaciones "mínimas" para los inversionistas extranjeros. Calificamos estas obiigaciones como "mínimas", porque nada impide que nuevos textos legales, nacionales o comunitarios, agreguen nuevas obligaciones a las ya existentes.

Resuitaría largo e inadecuado para este tipo de trabajo el enumerarlas todas, más aún cuando ellas están prácticamente tratadas a lo largo del presente estudio. Son obligaciones, por ejemplo, las que debe contraer la empresa extranjera para su transformación en empresa mixta o nacional (Capítulo III); son obligaciones también, los trámites necesarios para la autorización, registro y control de las inversiones extranjeras y de los contratos sobre importación de tecnologia; son obligaciones los trámites necesarios para obtener créditos externos, etc. etc. $\mathbf{Y}$, además, lo que es obligación para una parte, es derecho a exigir de otra, y viceversa.

En todo caso, deberá tenerse presente lo dispuesto en el artículo 50 del Régimen Común:

"Los Países Miembros no concederán a los inversionistas extranjeros ningún tratamiento más favorable que el que otorguen a los inversionistas nacionales".

\section{Obligaciones y Derechos de los Países Miembros y de los Organos Co. munitarios.}

Existen sin embargo en la Decisión 24, una serie de obligaciones para los Paj. ses Miembros, e, inclusive, para los organos comunitarios. Ellas se relacionan con el fiel cumplimiento de las normas y principlios del Régimen Común, sea en 10 referente a las inversiones extranjeras, sea en cuanto a la tecnología, y también referente a algunas materias que estando ligadas a los dos problemas anteriores, no fué posible (por falta de tiempo o falta de acuerdo entre los países) tratarlas en la Decisión 24. A estas obligaciones nos referiremos a continuación.

1. Obligagiones para los Países Miembros que se relacionan con las Inversiones Extranjeras.

a) "Artículo 6: El control del cumplimiento de las obligaciones contraidas por los inversionistas extranjeros estará a cargo del organismo que re. gistra la inversión, en coordinación con las reparticiones o dependencias estatales competentes en cada caso. 
"Además de las funciones que se señalan en otras disposiciones del presente régimen y de las que se establezcan en el reglamento respectivo, corresponderá al organismo nacional competente (ONC):

a) Controlar el cumplimiento de los compromisos de participación nacional en la dirección técnica, administrativa, financiera y comercial en el capital de la empresa;

b) Autorizar en forma excepcional la compra de acciones, participaciones o derechos de empresas nacionales o mixtas por inversionistas extranjeros, conforme a lo establecido en los artículos 3 y 4 del presente régimen;

c) Establecer un sistema de información y control de los precios de los productos intermedios que suministren los proveedores de tecnología o capital extranjero;

d) Autorizar la transferencia al exterior, en divisas libremente convertib'es, de toda suma a cuyo envío tengan derecho las empresas o los inversionistas según el presente régimen y las leyes nacionales del país respectivo;

e) Centralizar los registros estadísticos, contables, de información y con. trol relacionados con la inversión extranjera directa; y

f) Autorizar los contratos de licencia para uso de tecnología importada y para la explotación de marcas y patentes".

b) "Artículo 46: Cuando se trate de proyectos que correspondan a productos reservados para Bolivia o el Ecuador por aplicación del artículo 50 del Acuerdo de Cartagena, los cuatro países restantes se comprometen a no autorizar inversión extranjera directa en sus territorios, salvo lo estipulado en contratos celebrados antes del 31 de diciembre de 1970".

c) "Artículo 48: Los Países Miembros se comprometen a mantenerse recíprocamente informados y a informar a la Junta acerca de la aplicación del presente régimen en sus territorios $\mathrm{y}$ en especial sobre las normas del Capítulo II. Asimismo, se comprometen a establecer un sistema perma. nente de intercambio de informaciones sobre las autorizaciones de inversión extranjera o de importación de tecnología que otorguen en sus territorios con el objeto de facilitar una creciente armonización de sus políticas y de mejorar su capacidad de negociación para obtener condiciones no menos favorables para el país receptor que aquellas que se hayan negociado en casos similares con cualquier otro País Miembro.

Asimismo, se comprometen a coordinar estrechamente su acción en los organismos y foros internacionales que consideren materias relacionadas con inversiones extranjeras o transferencia de tecnología".

La última disposición es de gran trascendencia, porque ella constituye, además, de una obligación, el objetivo principal del Régimen Común, es decir, actuar como una sola gran Nación frente al mundo económico exterior. Ocurría que los inversionistas extranjeros aprovechaban las diferentes legislaciones somo 
instrumento de presión: insinuaban que siendo más favorable el tratamiento en otro país, postergaban su decisión de inversión. Al tener los cinco países un criterio común, a través de la armonización de sus políticas, este peligro desaparece considerablemente.

d) "Artículo 2 inciso II: La Comisión, a propuesta de la Junta, podrá aprobar criterios comunes para la evaluación de la inversión extranjera directa en los Países Miembros".

Naturalmente que es ésta una facultad o derecho de la Comisión, y una obligación para los Paises Miembros, en cuanto deberán aceptar los critexlos comu. nes de evaluación que se aprueben en Lima.

2. Obligaciones que se relacionan con la importación de tecnologia.

a) Obligaciones para los Países Miembros:

a.1) "Artículo 6 inciso II: Ad'emás de las funciones que se sefialan en otras disposiciones del presente régimen y de las que se establezcan en el regamento respectivo, corresponderá al ONC:

c) Establecer un sistema de información y control de los precios de los productos intermedios que suministren los proveedores de tecnologia 0 capital extranjero;

f) Autorizar los contratos de licencia para uso de tecnología importada y para la explotación de marcas y patentes".

a.2.) "Artículo 22: Las autoridades nacionales emprenderán una tarea continua y sistemática de identificación de las tecnologías disponibles en el mercado mundial para las distintas ramas industriales, con el fin de disponer de las soluciones alternativas más favorables y convenientes para las condiciones económicas de la Subregión y remitirán los resultados de sus trabajos a la Junta. Esta acción se adelantará en forma coordinada con las que en el Capítulo $\mathrm{V}$ de este régimen se adopten en relación con la producción de tecnología nacional o subregional".

a.3.) "Artículo 24: Los Gobiernos de los Países Miembros darán preferencia en sus adquisiciones a los productos que incorporen tecnología de origen subregional en la forma que la Comisión estime conveniente. La Comisión, a propuesta de la Junta podrá proponer a los Países Miem. bros el establecimiento de gravámenes a los productos que utilicen marcas de origen extranjero que den lugar al pago de regalías, cuando en su elaboración se emplee tecnología de publico conocimiento o fácil acceso".

a.4.) "Artículo 54: Los Países Miembros crearán una Oficina Subregional de Propiedad Industrial que tendrá las siguientes funciones:

a) Servir de órgano de enlace entre las oficinas nacionales de propledad industrial; 
b) Recopilar y difundir informaciones sobre propiedad industrial a las oficinas nacionales;

c) Preparar contratos tipo de licencia para el uso de marcas o explotación de patentes en la Subregión;

d) Asesorar a las oficinas nacionales en todos los asuntos relacionados con la aplicación de las normas comunes sobre propiedad industrial que se adopten en el reglamento a que se refiere el artículo transitorio $G$ ); e) Adelantar estudios y presentar recomendaciones a los Países Miembros sobre patentes de invención".

a.5.) "Artículo C) Transitorio: Mientras no entre en vigor el reglamento previsto en el artículo G) Transitorio del presente régimen, los Países Miembros se abstendrán de celebrar unilateralmente convenios sobre propiedad industrial con terceros países".

Como se ha visto anteriormente, el artículo G) Transitorio disponía que dentro de los seis meses siguientes a la entrada en vigor del régimen común (o sea. entre el 30 de junio de 1971 y el 31 de diciembre de ese mismo año), la Comisión, a propuesta de la Junta, debía adoptar un reglamento para la aplicación de las normas sobre propiedad industrial. En la Reunión de la Comisión celebrada en Lima, en diciembre último, no se adoptó sin embargo este reglamento, y la decisión pertinente fué postergada para el mes de Mayo de 1972.

\section{b) Obligaciones para los Organos Comunitarios:}

b.1.) "Artículo 23: La Comisión, a propuesta de la Junta, aprobará, antes del 30 de noviembre de 1972, un programa encaminado a promover y proteger la producción de tecnología subregional, así como la adaptación y asimilación de tecnologías existentes.

Este programa deberá contener, entre otros elementos:

a) Beneficios especiales, tributarios o de otro orden, para estimular la producción de tecnología y especialmente de las relacionadas con el uso intensivo de insumos de origen subregional o que estén diseñadas para aprovechar eficazmente los factores productivos subregionales;

b) Fomento de las exportaciones a terceros países de productos elaborados a base de tecnología subregional; y

c) Canalización de ahorro interno hacia el establecimiento de centros subregionales o nacionales de investigación y desarrollo".

b.2.) "Artículo 55: La Comisión, a propuesta de la Junta, establecerá un sistema subregional para el fomento, desarrollo, producción y adaptación de tecnologia, que tendrá a su cargo, además, la función de centralizar la información a que se refiere el artículo 22 del presente régimen y difundirla entre los Países Miembros, junto con la que obtenga directamente sobre las mismas materias y sobre las condiciones de comercialización de la tecnología".

b.3.) "Artículo F) Transitorio: Dentro de los seis meses siguientes a la entrada en vigor del presente régimen (es decir, hasta el 31 de diciembre de 1971), 
la Comisión, a propuesta de la Junta, aprobará el reglamento de la Oficina Subregional de Propiedad Industrial".

b.4.) Antes del 30 de noviembre de 1972 la Comisión, a propuesta de la Junta, adoptará las medidas necesarias para armonizar el régimen de incentivos aplicables a ciertos sectores económicos, excluido el sector llamado de "fomento industrial".

El reglamento a que alude el artículo antes transcrito, tampoco adoptado en la reunión de diciembre de la Comisión del Acuerdo de Cartagena, y la decisión pertinente quedó diferida para el mes de mayo de 1972.

3. Derechos que se relacionan con las Inversiones Extranjeras o la Tecnología, para los Países Miembros o los Organos Comunitarios (Comisión \& Junta).

a) "Artículo 49: Sin perjuicio de lo dispuesto en los artículos 79, 81 y 99 del Acuerdo de Cartagena, cualquier País Miembro que se considere perjudicado por importaciones de productos de empresas extranjeras, efectuadas al amparo del programa de liberación de dicho Acuerdo, podrá solicitar a la Junta autorización para udoptar las medidas correctivas necesarias para evitar el perjuicio".

b) "Artículo 52: Conforme a lo dispuesto en el presente régimen y en el $\mathrm{Ca}$ pitulo II del Acuerdo de Cartagena, corresponden a la Comisión y a la Junta las siguicntes facultades:

"A la Comisión

a) Decidir sobre las propuestas que la Junta eleve a su consideración respecto del tratamiento a los capitales extranjeros, propiedad industrial y del sistema de producción y comercialización de tecnología, en cumplimiento del presente régimen;

b) Aprobar, a propuesta de la Junta, los reglamentos que sean necesarios para la mejor aplicación del régimen común; y

c) Adoptar las demás medidas que tiendan a facilitar la consecucion de sus objetivos.

“A la Junta

a) Velar por la aplicación y el cumplimiento del régimen y de los reglamentos que sobre la materia apruebe la Comisión;

b) Centralizar la información estadística, contable o de cualquier otra naturaleza relacionada con la inversión extranjera o transferencia de tecnología, proveniente de los Paises Miembros;

c) Acopiar información económica y jurídica sobre la inversión extranjera y transferencia de tecnología y suministrarla a los Países Miembros; y

d) Proponer a la Comisión las medidas y los reglamentos necesarios para la mejor aplicación del presente régimen".

En la adopción de decisiones sobre las materias comprendidas en el presente réginıen, la Comisión se sujetará al procedimiento establecido en el literal a) del artículo 11 del Acuerơo de Cartagena. (Artículo 53)

90 


\section{Obligación de aprobar un Convenio de doble Tributación.}

En virtud del artículo 47 de la Decisión 24, la Comisión, a propuesta de la Junta, debía aprobar, a más tardar el 30 de noviembre de 1971, un convenio destinado a evitar la doble tributación entre los Países Miembros, $y$ un convenio tipo para la celebración de arreglos sobre doble tributación entre los Países Miembros y otros estados ajenos a la subregión. Entretanto, agregaba el artículo, los Países Miembros se abstendrán de celebrar convenios de esta naturaleza con ningún país ajeno a la subregión.

Los convenios en cuestión fueron aprobados por la Decisión No 40, y el Presidente de la República deberá enviar al Congreso Nacional el Mensaje correspondiente dentro de poco tiempo.

VII. Se establecen normas especiales para ciertos sectores de la Economía.

Hemos dicho anteriormente que el Régimen Común establece un conjunto de obligaciones "mínimas" para el inversionista extranjero, y que el Estado puede crear nuevas. El artículo 38 de la Decisión 24 no hace sino corroborar esto último al disponer que:

"Cada País Miembro podrá reservar sectores de actividad económica para las empresas nacionales, públicas o privadas y determinar si se admite en ellos la participación de empresas mixtas.

"Sin perjuicio de lo dispuesto en otros artículos del presente Capítulo, la Comisión, a propuesta de la Junta, podrá determniar los sectores que todos los Países Miembros reservarán para las empresas nacionales, públicas o privadas, y establecer si se admite en ellos la participación de empresas mixtas".

\section{Sectores prohibidos para la inversión extranjera.}

Sir perjuicio de lo dicho, la Decisión 24 establece una serie de sectores en donde está prohibida la inverísión extranjera directa. Antes de entrar al estuaio de cuáles son esos sectores, vale la pena consignar que, en la práctica, esta prohibición queda derogada por el propio artículo 44 del Régimen Común, que establece que "cuando a juicio del país receptor existan circunstancias especiales, dicho país podrá aplicar normas diferentes a las previstas en los artículos 40 a 43 inclusive". Es indudable que podría caerse en una interpretación un tanto jigera đe los términos "circunstancias especiales", que desvirtuara todo el capítulo relativo a las prohibiciones.

Los sectores prohibidos para la inversión extranjera directa son:

\section{1.) Sector de Servicios Públicos.}

“Artículo 41: No se admitirá el establecimiento de empresas extranjeras ni nueva inversión extranjera directa en el sector de servicios públicos. So excep- 
tuaan de esta norma las inversiones que tuvieren que realizar las empresas extranjeras actualmente existentes para operar en condiciones de eficiencia técnica y económica.

"Para estos efectos, se consideran servicios públicos los de agua potable, alcantarillado, energía eléctrica y alumbrado, aseos y servicios sanitarios, teléfonos, correos y telecomunicaciones".

2. Sector de los seguros, banca comercial y demás instituciones financieras.

" $\Lambda$ rtículo 42: No se admitirá nueva inversión extranjera directa en el sector de los seguros, banca comercial y demás instituciones financieras.

"Los bancos extranjeros actualmente existentes en el territorio de los Países Miembros dejarán de recibir depósitos locales en cuenta corriente, en cuenta de ahorro o a plazo fijo, dentro de un plazo de tres años contados desde la entrada en vigor del presente régimen.

"Los bancos extranjeros actualmente existentes que deseen continuar recibiendo depósitos locales de cualquier especie deberán transformarse en empresas nacionales, para cuyo efecto pondrán en venta acciones que correspondan por 10 menos al $80 \%$ de su capital para su ađquisición por inversionistas nacionales dentro del plazo señalado en el inciso anterior".

3. Otros sectores: transporte interno, publicidad, radioemisoras comerciales, estaciones de televisión, periódicos, revistas, empresas dedicadas a la comercialización interna de productos de cualquier especie.

En estos sectores tampoco se admitirá nueva inversión extranjera directa. Las empresas extranjeras que operen actualmente en estos sectores deberán transformarse en empresas nacionales, para cuyo efecto deberán poner en venta por lo menos el $80 \%$ de sus acciones para su adquisición por inversionistas nacionales en un plazo no mayor de tres años, contados a partir del 30 de junio de 1971. (Artículo 43)

\section{Sector de productos básicos.}

Por sector de productos básicos se entiende el que comprende las actividades primarias de exploración y explotación de minerales de cualquier clase (cobre, por ejemplo), incluyendo los hidrocarburos líquidos y gaseosos, gaseoductos, oleoductos y la explotación forestal.

Estc sector, tan históricamente ligado a las economías de los países en vías de desarrollo, y, que en el caso de los países andinos, constituye la "viga maestra" o el "sueldo" de estos pueblos, resulta difícil integrarlo, ya que esto implicaria desmontar todo un instrumental jurídico e industrial enorme y en el caso de 
algunos países, sustraerse a compromisos internacionales ineludibles. Piénsese to que significaría para Chile entrar a modificar la reciente legislación cuprffera, y a hacer los cambios necesarios en equipos e instalaciones, para integrarnos con Perú. Por ello es que la Integración Económica se dirige, en un comienzo a sectores más dinámicos. De ahí el tratamiento diferente que se les dá en el artículo 40 de la Decisión 24.

Ei tratamiento diferente consiste en lo siguiente: Durante los 10 primeros años de vigencia del Régimen Común se podrá autorizar la actividad de empresas extranjeras en el sector de productos básicos, pero bajo el sistema de concesiones, y siempre que el plazo đel contrato respectivo no exceda de 20 años .(Artículo 40 unciso I)

Los Países Miembros no autorizarán deducciones por agotamiento para fines tributarios a las empresas que inviertan en este sector. (Artículo 40 inciso III)

La participación de empresas extranjeras en la exploración y explotación de yacimientos de hidrocarburos líquidos y gaseosos se autorizará preferentemente en la forma de contratos de asociación con empresas del Estado del país receptor. (Artículo 40 inciso IV)

Los Países Miembros podrán acordar a las empresas extranjeras establecidas en este sector tratamientos diferentes a los previstos en el artículo 37 de la Decisión 24. (El menctonado artículo establece que los inversionistas extranjeros tendrán derecho, previa autorización del ONC, a transferir al exterior, en đivisas libremente convertibles, las utilidades netas comprobadas que provengan de la inversión extranjera directa, sin pasar del $14 \%$ anual de la misma).

Cabe señalar que el tratamiento a los sectores básicos no es, sin embargo, un tratamiento riguroso, por cuanto el ya mencionado artículo 44 establece que "cuando a juicio del pais receptor existan circunstancias especiales, dicho pais podrá aplicar normas diferentes a las previstas". De esta manera, los países andinos podrán por largo tiempo mantener sus industrias básicas al margen del proceso de integración.

\section{Normas generales para los sectores especificos.}

Las empresas extranjeras que operan en los sectores antes señaladios, no están obligadas a sujetarse a lo dispuesto en el Capítulo II de la Decisión 24 sobre transformación de empresas extranjeras en empresas nacionales o mixtas. Sin embargo estarán sometidas a las demás disposiciones del régimen común y a las especiales que han sido detalladas. (Artículo 39).

Los productos de las empresas extranjeras que operen en estos sectores que no convengan su transformación en empresas nacionales o mixtas 0 respecto de las cuales los Países Miembros apliquen las normas diferentes a que se refiere el articulo 44, no podrán gozar naturalmente de las ventajas del programa de liberación del Acuerơo de Cartagena. (Artículo 44 inciso II). Esto es una conse- 
cuencia de los principios sobre transformación contenidos en el Capítulo II. (Artícuios 29. y 32)

\section{El Régimen Común y las leyes de fomento industrial.}

En virtud del Artículo $H$ ) Transitorio, los Países Miembros se comprometían a no establecer incentivos a la inversión extranjera diferentes a los contemplados en sus legislaciones de fomento industrial al 30 de junio de 1971, mientras no se cumpliera el compromiso previsto en el artículo 28, inciso segundo, del Acuerdo de Cartagena, sobre armonización de las legislaciones de fomento industrial.

En diciembre de 1971, la Comisión aprobó la Decisión No 49, sobre "Directivas para la armonización de las legislaciones sobre Fomento Industrial". Nos remitimos, en consecuencia, a dicha Decisión. 